\title{
Substantive Justice and Speedy Trial in the Regional Head Election Disputes in the Constitutional Court
}

\author{
Oly Viana Agustine \\ \{olyviana@mkri.id\} \\ Center of Research and Case Studies, Indonesian Constitutional Court, Indonesia
}

\begin{abstract}
The Constitutional Court as a transitional court until the establishment of a special election court that adjudicates regional head election disputes has been given restrictions in the procedural law in accordance with the provisions of the laws and regulations. One of the limitations is the provision of acceptance of dispute requests, namely 3 working days after the announcement of the decision by the Regional Election Commission. This provision is in line with the principle of speedy trial in resolving regional head election disputes. In this research, we will discuss about how substantive justice and the application of speedy trial Regional Head election dispute at the Constitutional Court. This research is needed in order to obtain a balance and proportionality between the two principles applied in the settlement of regional head election disputes at the Constitutional Court. The research method used is normative juridical with a case study approach to dispute over the results of the 2020 regional head election in the Constitutional Court. The results showed that there were 5 (five) constituencies that were violated by the provisions related to the grace period for receiving applications at the Constitutional Court, namely 3 (three) working days after the announcement of the Regional Election Commission. The six cases are the dispute over the Election of Pesisir Barat Regency, Bandung Regency, Samosir Regency, Nabire Regency and 2 (two) Sabu Raijua Regencies. The deviation made by the Constitutional Court against the provision on the grace period for submitting an application which is a formal requirement for a petition is based on the existence of a casuistic problem in each electoral district where there is no legal rule in the statutory regulations requiring resolution.
\end{abstract}

Keywords: Constitutional Court, Regional Head Election Dispute, Speedy Trial, Substantive Justice

\section{Introduction}

The debate between formal justice and substantive justice has never been absent in Regional Head Election disputes from year to year. The settlement of Regional Head Election disputes which is bound to formal procedural law creates a gap in the need for substantive justice. Formal procedures in the process of examining and adjudicating cases of Regional Head Election disputes require legal certainty in accordance with what is written in the laws and regulations. Meanwhile, substantive justice demands on how a case can be resolved with the complex problems underlying the case, so that an in-depth examination is needed and not just formal legalism. This has also happened a long time ago in other trials as stipulated in the Speedy Trial Act of 1974 which set a time limit so that raised widespread concern about the impact on the 
operation of the Federal justice system. Many praised the law as a decisive steps in delaying congestion. while others argue that the speedy trial will have the effect of complicating court matters Debates about speedy trials are frequent, no simple answers to complex problems [1].

The formal procedure for resolving disputes for Regional Head Election includes, among other things, a time limit of 45 (forty five) working days in accordance with the provisions of the laws and regulations for the settlement of Regional Head Election disputes. The count of 45 working days is marked by the commencement of a case that has been received and registered by the Constitutional Court. Acceptance of applications for Regional Head Election disputes is also given a time limit in accordance with statutory regulations, namely 3 (three) working days after the Provincial/Regency/City General Election Commission (KPU) delivers an announcement regarding the final result of the vote acquisition for the Regional Head election.

With the stipulation of the 3 (three) working days time limit for filing a request for a dispute over the Regional Head Election at the Constitutional Court, of course it has a juridical impact. As stipulated in the laws and regulations, if the application is submitted after the deadline for submitting the application, the application will be terminated with an unacceptable warning (niet ontvankelijk verklaard/NO). The provision for a grace period of 3 (three) working days for filing the application is one part of the formal requirements that must be fulfilled by the Petitioners. Thus, if the 3 (three) working day grace period for filing the application is not fulfilled, then it will have the same legal consequences as not fulfilling other formal requirements such as incomplete documents or unclear identity of the Petitioner and so on. As applied, all timeprecise speedy trial statutes and rules are in some respects stricter, and in some respects more lax, than constitutional speedy trial rights [2].

Legal problems arise when there are casuistic conditions that cause applications to be submitted late or exceed the 3 (three) working days time limit as stipulated in the statutory regulations. These conditions have not been anticipated by the provisions of laws and regulations. This was found in the dispute over the results of the regional head election at the Constitutional Court in 2020. Namely in the 2020 Regional Head Election, there were elected pairs of regional heads with dual citizenship status, namely in the regional head elections in Sabu Raijua Regency. The fact of the existence of dual citizenship in the elected Regional Head candidates is known long after the Regional Head Election process has been completed. Meanwhile, there is not a single provision in the statutory regulations that accommodates this situation.

Of course, by starting with a formal perspective in responding to the case of the Regional Head Election in Sabu Raijua Regency, the Constitutional Court could not accept the request. However, this is where the meeting point of the Constitutional Court's legal search and discovery in realizing substantive justice. Based on these problems, it was found that in the 2020 Regional Head Election, there were several cases that made the Constitutional Court have to make legal breakthroughs by setting aside the 3 (three) working days grace period upon receipt of the Petitioner's petition. Based on this description, this research will discuss how the Constitutional Court's efforts in realizing the fulfillment of substantive justice in the application of the speedy trial in resolving disputes for the 2020 Regional Head election in the Constitutional Court. 


\section{Method}

The major aim of any type of research is to find out the reality and facts which is unknown and which has not been exposed [3]. The research method used is to use the normative method with a case approach. This method is used by observing how the procedural law provisions in both laws and regulations of the Constitutional Court regulate the grace period in disputes over the results of regional head elections. The case approach is used to see problems at the implementation level and how the Constitutional Court provides solutions to these problems. The cases used as research objects are 6 (six) cases in 5 (five) electoral districts that have been examined and decided by the Constitutional Court in disputes over the results of the 2020 regional head election. Case Number 39/PHP.BUP-XIX/2021, Bandung Regency in Case Number 46/PHP.BUP-XIX/2021, Samosir Regency in Case Number 100/PHP.BUP-XIX/2021, Nabire Regency in Case Number 84/PHP.BUP-XIX/2021, and Sabu Raijua Regency in Case Number 133/PHP.BUP-XIX/2021 and 135/PHP.BUP-XIX/2021. Of the six cases, an analysis was then carried out by taking an inventory of decisions and identification based on the provisions regarding the grace period, so that problems were obtained regarding the existence of deviations from the provisions of the grace period as regulated in the legislation.

\section{Results and Discussion}

\subsection{Provisions on the Deadline in the 2020 Regional Head Election Dispute Procedure Law at the Constitutional Court}

Provisions related to the procedural law for the 2020 Regional Head election disputes at the Constitutional Court are specifically contained in the Constitutional Court Regulation Number 6 of 2020 concerning Procedures for Dispute Cases in Election Results of Governors, Regents and Mayors, Constitutional Court Regulations Number 7 of 2020 and 8 of 2020 concerning Stages, Activities and Schedules for Handling Dispute Cases on the Results of the Election for Governors, Regents and Mayors. In these two regulations, complete and specific arrangements for the stages of case handling as well as the procedures for drafting applications. The provisions of the Court's procedural law which are regulated through the Constitutional Court Regulation are made possible based on Article 86 of the Constitutional Court Law which gives the Constitutional Court the authority to further regulate the matters required for the smooth implementation of its duties and powers.

Provisions on the Deadline for Receiving Applications in Disputes over Regional Head Election Results are regulated in Article 157 paragraph (5) of Law 10/2016 and Article 1 number 31 as well as Article 7 paragraph (2) and Article 9 paragraph (7) of the Constitutional Court Regulation Number 6 of 2020 concerning Procedures for Dispute Cases in Election Results for Governors, Regents, and Mayors (PMK 6/2020), as well as General Election Commission Regulation Number 19 of 2020 concerning Amendments to General Election Commission Regulation Number 9 of 2018 concerning Recapitulation of Vote Count Results and Determination of Governor Election Results And the Deputy Governor, Regent and Deputy Regent, and/or Mayor and Deputy Mayor (PKPU 5/2020), respectively as follows:

“Article 157 paragraph (5) of Law 10/2016 states that: "Election participants submit a request to the Constitutional Court as referred to in paragraph (4) no later than 3 
(three) working days from the announcement of the determination of the vote acquisition results of the Election by the Provincial KPU or Regency KPU/City KPU"; Then Article 7 paragraph (2) PMK 6/2020 states that: "The application as referred to in paragraph (1) shall be submitted no later than 3 (three) working days after the announcement of the determination of the votes acquired by the Respondent of the Election results"; Whereas in Article 1 number 31 PMK 6/2020 states that: "Working days are working days of the Constitutional Court, namely Monday to Friday, except for official holidays stipulated by the Government". Then in Article 9 paragraph (7) PMK 6/2020 states, that "the working day as referred to in Article 7 paragraph (2), is effective from 08.00 WIB up to 24.00 WIB"; and Article 31 paragraph (5) PKPU 19/2020 states, that "Regency KPU/ City KPU / KIP announces the District/City-KWK Model D. Result form and a copy of the Decree as referred to in paragraph (2) for the Election of the Regent and Deputy Regent or Mayor and Deputy Mayor on the website of Regency KPU/City KPU/KIP and/or a place that is easily accessible to the public for 7 (seven) days".

Based on the above provisions, it can be concluded that based on Article 157 paragraph (5) of Law 10/2016 and Article 7 paragraph (2) PMK 6/2020, the deadline for submitting a request for cancellation of the Final Vote Determination of Election Results is no later than 3 (three) days. work since the Respondent announced the determination of the vote acquisition results of the election. With respect to applications submitted beyond the deadline for filing applications as regulated in Article 157 paragraph (5) of Law 10/2016 and Article 7 paragraph (2) PMK $6 / 2020$, the applicant's petition cannot be accepted. This is in accordance with Article 55 PMK $6 / 2020$ which states that the application decision cannot be accepted, (niet onvankelijk verklaard) if the Petitioner's petition does not meet the formal requirements of the application.

\subsection{Principles of Speedy Trial in Disputes over the Results of Regional Head Elections}

The principle of speedy trial itself is part of a principle long known in a court of law which mandates a fast, simple and low cost process. From this principle it mandates that the process of examining and deciding a case from a judicial institution must be carried out quickly, simply and at low cost and must be applied consequently at all levels of the judiciary [4]. This principle has been listed since the existence of Herziene Inlandsch Reglement (HIR), for example Article 71 calls it "once twenty-four hours"; which has a more definite meaning than the term "immediately" (which is widely included in the provisions of the Criminal Procedure Code), as well as the term "in the shortest possible time", to indicate a fast judicial system [5]. The inclusion of a fast trial (contante justitie; speedy trial) in the criminal procedure law, especially to avoid long detention before a judge's decision is made, is part of human rights; Likewise with a free, honest and impartial trial [6].

This principle was then reformulated in Law Number 48 of 2009 concerning Judicial Power, Chapter II, concerning the Principles of Implementing Judicial Power, as stipulated in Article 2 paragraph (4), which requires that every trial be carried out simply, quickly and at low cost. The description of the principle of a trial that is fast, precise, and low cost, among others, the suspect/defendant has the right [7]: to immediately be examined by the investigator, immediately submitted to the public prosecutor by the education officer, immediately submitted to court by the public prosecutor, and has the right to be tried immediately by the court. The principle of justice is carried out simply, quickly, and at low cost and does not only apply to 
criminal or civil procedural law. In disputes over the election of a Regional Head, it is also closely related to the speedy trial process, known as the speedy trial.

In resolving disputes over the Regional Head Election at the Constitutional Court using the speedy trial principle. The use of the speedy trial principle in disputes over regional head elections has received various pros and cons responses. This is because there is an opinion from some people who state that implementing rapid justice can conflict with aspects of Justice. The judiciary quickly makes the case examination process time-limited as determined by statutory regulations. Even though it is the obligation and authority of the Constitutional Court to explore the real truth as one of the objectives of the law.

In reality, speedy trial is not a wrong thing in the world of justice. A speedy trial is needed so that an issue can be resolved quickly. A speedy trial is needed in order to reduce existing conflicts as a result of a Regional Head election. Some people argue that obedience to the principle of speedy trial in regional head election disputes is necessary because whatever the type of violation actually requires a legally binding decision in a short time. So that in electoral matters, certainty is needed in the resolution mechanism. Thus, the judiciary in electoral matters must be viewed as one form or type of speedy trial, the process of which is sufficiently carried out with a fair legal certainty approach and on the principle of formal proof only [8]. Therefore, in every election dispute and regional head election that is included in the category of speedy trial, it requires each party to prepare applications, answers, and statements in a relatively fast time with a high precautionary principle in preparing tools evidence [9].

Fast trial is also related to the goal of legal certainty in the electoral process. Legal certainty is also related to the capacity of dispute resolution institutions, in this case the Constitutional Court, to decide disputed cases quickly. Thus, if the Constitutional Court's decision grants the petitioner's petition, then the legal action to restore the right is still within the scope of the ongoing electoral process stages [9]. Such actions by the Constitutional Court are related to the capacity of the election process dispute settlement institutions in assessing and resolving disputes between the parties based on the provisions of election law, both statutory regulations and legal principles relating to the election.

\subsection{Extension of the Deadline for Acceptance of Applications as Efforts to Find Substantive Justice in Disputes over the Results of Regional Head Elections}

In the implementation of the 2020 Regional Head Dispute, the Constitutional Court received 6 (six) cases from 5 (five) electoral districts that have passed the deadline. With regard to the six cases, the Constitutional Court continued to examine and continue the case up to the case examination stage with the agenda of the trial of evidence. The six cases, namely:

a. The Election Dispute of Pesisir Barat Regency in Case Number 39/PHP.BUP-XIX/2021.

b. The Election Dispute of Bandung Regency in Case Number 46/PHP.BUP-XIX/2021.

c. The Samosir Regency Election Dispute in Case Number 100/PHP.BUP-XIX/2021.

d. The Election Dispute of Nabire Regency in Case Number 84/PHP.BUP-XIX/2021.

e. The Election Dispute of Sabu Raijua Regency in Case Number 134/PHP.BUP-XIX/2021 and 135/PHP.BUP-XIX/2021.

From the six cases, it can be concluded that there are constitutional reasons that caused the Constitutional Court to set aside the deadline for submitting the Petitioner's petition, namely as follows:

a. There are legal facts about the absence of convincing evidence when the announcement through the announcement board was made by the KPU, which led to the Constitutional Court of the opinion that the petition was declared not past the deadline. 
b. There are legal facts in the form of a statement made by the Respondent regarding the deadline for submitting a petition for objection to the election results of the Regent and Deputy Regent to the Constitutional Court, which according to the Court the Respondent's statement constitutes an official notification/announcement that is integrated into the schedule/stages of the election program. Thus, the Court is of the opinion, the Petitioner's petition does not violate the deadline for filing the Petitioner's petition as determined by the prevailing laws and regulations.

c. There are legal facts that were revealed in the trial where the verdict was announced through an announcement board without being announced on the KPU website.

d. There are legal facts where the Permanent Voters List is invalid and illogical and voting is not done using a direct voting system.

e. There are legal facts that are only known and questioned after the completion of the recapitulation stages of vote count results and the determination of the elected candidate pair, and the elected candidate pair has not been appointed as regional head, which is an unprecedented legal event. Such events have not been anticipated in the laws and regulations which cause legal uncertainty in the completion of the said election stages.

From the five explanations above, it shows that the Constitutional Court has fulfilled substantive justice by extending time in receiving petitions. The Constitutional Court's actions are such, given that the constitution as the highest law regulates state administration in this case justifies the attitude of the Constitutional Court of extending the time for acceptance of applications. The extension of time to receive requests is based on democratic principles and protects human rights. This is consistent with the Constitutional Court which functions as the guardian of democracy, the protector of the citizen's constitutional rights and the protector of human rights [10].

Waiving the grace period by extending the acceptance of applications is a development practice in the Constitutional Court in resolving Regional Head Election disputes in 2020 which is a manifestation of upholding substantive justice. The Constitutional Court made a legal breakthrough in resolving Regional Head Election disputes in 2020 without neglecting the principle of speedy trial. The enforced substantive justice shifts procedural justice by not allowing procedural justice rules to override substantive justice.

The priority of substantive justice is due to the existence of legal facts found in the trial process casuistically violating the constitution. These violations include, among other things, violations of democratic principles and general election principles that are direct, general, free, secret, honest and fair as stipulated in Article 22E paragraph (1) of the 1945 Constitution. Pesisir Barat in Case Number 39/PHP.BUP-XIX/2021, Dispute on the Election Results of Bandung Regency in Case Number 46/PHP.BUP-XIX/2021, Dispute on Election Results of Samosir Regency in Case Number 100/PHP.BUP-XIX/2021, and Disputes over the Election Results of the Regent and Deputy Regent of Nabire Regency, Papua Province in Case Number 84/PHP.BUP-XIX/2021, as well as the Dispute on the Election Results of Sabu Raijua Regency in Case Number 134/PHP.BUP-XIX/2021 in Case Number 135/PHP.BUP-XIX/2021.

Enforcement of substantive justice by itself does not mean that the Court ignores the sound of statutory provisions regarding grace periods. As long as the provisions of the law regarding the grace period provide a sense of justice, the Constitutional Court will make it the basis for making a decision. Conversely, if the application of the provisions of the law regarding the grace period cannot provide justice because of violations that are against the constitution, the Constitutional Court can ignore it and then make its own decisions for the sake of substantive 
law enforcement. Substantive law enforcement implies a message of learning and education so that at the next Regional Head Election, such violations will not occur again.

The need for a breakthrough made by the Constitutional Court is due to the opinion that judicial institutions such as the Constitutional Court are capable of filling the legal vacuum. The judiciary is an institution that is believed to be able to resolve disputes that arise as a result of disputes over election results. Robert A. Carp, Ronald Stidham, and Kenneth L. Manning believe that in the context of legal politics in America, the significant role of the judiciary in fixing the political system is due to the ability of these institutions to protect democracy. Carp, Stidham, and Manning in full mention that [11]:

"The legal subculture has an impact on American jurists. Evidence shows that popular democratic values - manifested in a variety of ways through many different mediumshave an influence as well. Some scholars have argued that the only reason courts have maintained their significant role in the American political system is that they have learned to bend when the democratic winds have blown. That is, judges have tempered rigid legalism with commonsense popular values and have maintained "extensive linkages with the democratic subculture".

The six decisions above are an illustration of the many decisions of the Constitutional Court that have shifted from procedural justice in Regional Head Election disputes by prioritizing the concept of substantive justice. As with judicial review, in a Regional Head election dispute, apart from protecting the constitutional rights of citizens which should be protected, there are also election principles which are part of the constitutional values. By basing on the violation of the constitutional rights of citizens and the principles in the General Election, it becomes a justification for the Constitutional Court to break through substantive justice by setting aside the grace period for receiving the Petitioner's petition. The assistance carried out by the Constitutional Court was not automatically carried out without constitutional reasons, but the Court was based on the existence of legal facts that were ignored by the organizers and the existence of a legal vacuum.

The extension of the grace period for regional head election disputes is intended to uphold substantive justice and to provide benefits in upholding democracy and the constitution. The Constitutional Court has moved from procedural justice to substantive justice. This provision has also been repeatedly carried out by the Constitutional Court by deviating from the narrowly interpreted provisions of the law. The Constitutional Court is of the opinion that formal truth does not embody material truth so that it will be difficult to find justice that is beneficial in upholding democracy and the constitution. The Constitutional Court in adjudicating cases, not only refers to the formal object of election disputes, but also must explore and find the truth of law and justice in accordance with the evidence and convictions of judges. In an effort to realize procedural justice and substantive justice, as well as the principle of benefit for the supremacy of the constitution, law and democracy, the Constitutional Court has assessed all statements of the parties, evidence of letters, and witnesses at the trial in accordance with the duties and functions of the Constitutional Court as guardian of the constitution and democracy and protection of human rights [12].

To ensure the realization of direct regional head elections that are truly in accordance with the principles of democracy, their implementation and enforcement must be carried out with a system based on the principles of honesty and fairness, while at the same time proving that the implementation of the regional head elections did not have structured, systematic, and massive violations. This principle is applied in a good and integrative system, including: 1) availability 
of a material and formal legal framework that is applicable, is binding and serves as a guideline for organizers, contestants (pairs of candidates), and voters in carrying out their respective roles and functions; 2) the implementation of all activities or stages directly related to the implementation of regional head elections based on statutory provisions, (3) the integration of the electoral law enforcement process on the rules for regional head elections according to the stages at each level, whether related to administrative, criminal, ethical issues, and also disputes over results [13].

\section{Conclusion}

The results showed that there were 6 (six) cases in 5 (five) constituencies that were violated by the provisions related to the grace period for receiving applications at the Constitutional Court, namely 3 (three) working days after the announcement of the KPU. The six cases are the dispute over the election results of the West Coast District, Bandung Regency, Samosir Regency, Nabire Regency and Sabu Raijua Regency. The deviation made by the Constitutional Court against the grace period which is a formal requirement for a petition is based on the existence of casuistic problems in each electoral district where there is no legal rule in the statutory regulations that require resolution. Such actions by the Constitutional Court are part of the search and discovery of substantive justice without violating the principle of speedy justice in resolving disputes over regional head elections.

The spirit of the constitutional court must be upheld by prioritizing substantive justice in order to be able to prove the application of honest and fair democratic values as mandated by Article 24 of the 1945 Constitution. Electoral justice is an important instrument for upholding the law and ensuring the full application of democratic principles through the implementation of free, fair and honest elections. The justice system is developed to prevent and identify irregularities in elections, as well as as a means and mechanism to correct these irregularities and provide sanctions to perpetrators of violations [14].

\subsection{Suggestions}

The extension of time to receive requests for disputes over the results of regional head elections conducted by the Constitutional Court is an effort to find law in overcoming any legal problems that have not been regulated in statutory regulations. Nevertheless, a follow-up from legislators is needed to provide written rules in the implementation of disputes over the results of the upcoming regional head elections. The written provisions at the law level become a reference not only for regional head election organizers but also as a manifestation of the principle of legal certainty.

\section{References}

[1] B. O. Fort, Speedy Trial: A Selected Bibliography and Comparative Analysis of State Speedy Trial Provisions. Department of Justice, Law Enforcement Assistance Administration, National ..., 1978.

[2] G. P. N. Joseph, "Speedy Trial Rights in Application,” Fordham L. Rev., vol. 48, p. 611, 1979.

[3] S. B. Mishra and S. Alok, "Handbook of research methodology," Educreation, 2017.

[4] L. M. P. Pangaribuan, Hukum acara pidana: surat-surat resmi di pengadilan oleh advokat: 
praperadilan, eksepsi, pledoi, duplik, memori banding, kasasi, peninjauan kembali. Djambatan, 2002.

[5] D. E. Purwoleksono, "Laporan kegiatan Tim Naskah Akademik RUU tentang Hukum Acara Pidana." Jakarta: BPHN, 2010.

[6] A. Hamzah, "Hukum acara pidana Indonesia," 2001.

[7] M. Y. Harahap, "Pembahasan Permasalahan Dan Penerapan KUHAP Jilid II, Jakarta," Pustaka Kartini, 1988 .

[8] J. Asshiddiqie, "Peradilan Etik dan Etika Konstitusi," Sinar Graf., vol. 271, p. 22, 2014.

[9] A. Riwanto et al., Serial Evaluasi Penyelenggaraan Pemilu Serentak 2019: Perihal Penegakan Hukum Pemilu. Bawaslu, 2019.

[10] M. Konstitusi, "Mengawal Demokrasi Menegakkan Keadilan Substantif," Jakarta Lap. Tah. MK, 2009.

[11] R. A. Carp, K. L. Manning, L. M. Holmes, and R. Stidham, Judicial process in America. Cq Press, 2019.

[12] R. Surbakti, D. Supriyanto, and T. Santoso, Penanganan sengketa pemilu. Kemitraan bagi Pembaruan Tata Pemerintahan, 2011.

[13] H. Widodo, Hukum acara perselisihan hasil pilkada serentak di Mahkamah Konstitusi. Sinar Grafika, 2018.

[14] T. Lailam and P. Anggia, "Pengenyampingan Keadilan Substantif dalam Penerapan Ambang Batas Sengketa Hasil Pilkada di Mahkamah Konstitusi," J. Legis. Indones., vol. 17, no. 2, pp. 209-222, 2020. 